\title{
Evaluating Financial Sustainability of Higher Education Institutions
}

\author{
Sergei P. Sazonov ${ }^{1}$, Ekaterina E. Kharlamova ${ }^{1}$, Irina A. Chekhovskaya ${ }^{1} \&$ Elena A. Polyanskaya ${ }^{1}$ \\ ${ }^{1}$ Volgograd State Technical University, Volgograd, The Russian Federation \\ Correspondence: Ekaterina E. Kharlamova, Volgograd State Technical University, 28, Lenina Avenue, \\ Volgograd, 400005, The Russian Federation. Tel: 78-44-224-8476. E-mail: sikaterina@mail.ru
}

Received: February 6, 2015 Accepted: March 9, 2015 Online Published: June 13, 2015

doi:10.5539/ass.v11n20p34

URL: http://dx.doi.org/10.5539/ass.v11n20p34

\begin{abstract}
Economic reforms and reforms in the educational sphere have contributed to the increase of the concern towards the efficiency of the activity of educational organizations and higher educational establishments, in particular. This deals with the increased competition in both international and national markets for educational services; the growth of informational openness of higher education establishments and the enhanced role of strategic planning. All these aspects are gradually leading to a new objective that faces higher education establishments, which is a necessity to demonstrate the efficiency of their education services and support it with definite indices. Under conditions of budgetary expenditures, the problem of financial sustainability and efficiency of higher education institutions is becoming urgent, being focused on searching for possibilities to develop education establishments. In this context, the most important issue deals with developing approaches for quantifying financial sustainability and identifying the directions and means of its rise. The article suggests the method for defining the financial sustainability of higher education institutions and discusses both the indices, applied for financial sustainability evaluation, and their threshold values.
\end{abstract}

Keywords: financial stability, efficiency, education establishment, solvency, funds, budgetary funding, extra-budgetary funds

\section{Introduction}

Financial sustainability will be one of the key challenges for universities in the next decade: only those institutions that have sound financial structures and stable income flows will be able to fulfil their multiple missions and respond to the current challenges in an increasingly complex and global environment. Indeed, financial sustainability is not an end in itself; it aims to ensure that university's goals are reached by guaranteeing that the institution produces sufficient income to enable it to invest in its future academic and research activities. Income diversification is a tool to achieve these goals if the conditions in which the universities operate allow and require it, taking account of the diverse contexts.

The massification of higher education, additional and tougher accountability requirements, new societal demands on institutions, and rising costs of human resources (pension costs, etc.) are only some of the triggers for increased costs that universities are confronted with.

Financial sustainability is one of the most important characteristics for evaluation of the financial situation of an establishment. Providing inventory and expenditures by the sources of their forming is the essence of financial sustainability, and solvency is its external manifestation. The ratio between inventories and sources of proprietary and borrowed funds for their forming defines a degree of financial sustainability (Stabislavchik, 2010).

The problem of financial sustainability of education establishments has recently become of a scientific interest, since Russia's economy was switched to the market principles of functioning; i.e., in the late 1980s (Belyakov, 2012). At that time, the problem was just considered as theoretically possible for the system of professional training as a result of changes in economic conditions, and no thorough analysis was done. Both the dramatic changes in economic relationships in education in the early 1990s and the cut of budgetary funding exacerbated the problem of economic sustainability. As a result, the developed suggestions were useful singularly without forming any algorithm for a goal-oriented activity. 


\section{Background and Methods}

The financial theory considers the concept of financial sustainability as the provision of financial independence, i.e. as the provision of maintaining both the break-even point of the share of equity in the total capital and solvency to an education institution (its ability to cover its current liabilities). The coefficients of institutions' financial sustainability are evaluated in accordance with their balance sheets (Kharlamova \& Sazonov, 2014).

Rymanov A. Y. associates financial sustainability with a company's solvency, representing it as a system of financial and economic relationships which create, allocate, and use funds, providing solvency in a long-term aspect (Rymanova, 2010).

Benderskaya O. B. and Chizhova E. N. suggest that financial sustainability provides a company with innovation-based reproduction on an expanded scale, creditability, competitive ability, and investment attractiveness (Benderskaya, 2012).

"The financial sustainability of Higher Education Institutions in England, which includes its duties to monitor the financial health and risk of institutions" (Department for Business, 2014)

Lucie Lapovsky: "To ensure financial sustainability, many colleges and universities are responding by experimenting with changes to their business models. For instance, some schools are changing their discounting policies and publishing much lower tuition prices; others are experimenting with four-year price guarantees, the length of time required to earn a degree, more vigorous recruitment of foreign students, partnerships with overseas institutions, and increased operational efficiencies - from streamlining back office functions to offering online learning to reach more students without incurring the added costs of facilities and faculty" (Lapovsky, 2014).

At the same time, there are few studies concerning the problem of the financial sustainability of an education institution both in Russia and worldwide.

The objective of the research is to develop the theory and methodology of managing the financial sustainability of an education institution as a comprehensive system of theoretical provisions, which integrates methodological basics and concept models for forming the informational and analytical system of evaluating, monitoring, and managing the financial sustainability of education institutions in order to define the strategic directions of their further development.

\section{Results}

In the present time, when under conditions of both globalization and growing competition on the education market, Russia's higher educational establishments have to comply with new severe requirements for both educational services and research work, it is undoubtedly necessary to renovate and upgrade the systems of higher education establishment management, aimed at improving the indices of efficiency of their activity.

Efficiency is a key indicator of performance quality for the system, which characterizes a degree of its ability to fulfill its function as intended. As far as the efficiency of education services of higher educational establishments is discussed, the main mission of such a service is both the possibility of further employment and graduates' implementation of the knowledge they have gained with help of these services (Kharlamova \& Sazonov, 2014).

If one refers to legislation, it is possible to explain the educational activity of a higher educational establishment as activity to the extent concerning conduction of the primary mission of the education establishment; i.e., training and labor market launch of definite high university degree specialists, retraining of specialists, advanced vocational training.

All educational activity efficiency indices for higher education establishments, in accordance with the procedure proposed by the researches T. V. Terentyeva and M. N. Kulakova, are divided into three groups (Terentyeva, 2012).

The higher education establishment, which efficiency of educational activity refers to the third group, is in the "high-risk group"; i.e., less than half the graduates of this institute work within their specialty. If the establishment demonstrates such indices over the course of three years, its further existence on the market for educational services is subject to being called into question.

The higher education establishment, which efficiency of educational activity refers to the second group, is in the "average class"; i.e., more than half the graduates of this institute work within their specialty. If the establishment demonstrates such indices, it should carry out a deep self-examination, find its weak traits, and possibly progress them towards optimal indices. 
The higher education establishment, which efficiency of educational activity refers to the first group, is a "leader in the market for educational services". Its main objective is possibly to maximize its indices, rather than decrease them. Such establishment is worthy not only to be highly ranked but also to be encouraged by the state through bonus supplements.

The financial stability of higher education institutions is the condition of its funds, their allocation and use, which provides the performance of the main activity and the development of a higher education institution, based on capital growth using both budgetary and extra-budgetary funds, while maintaining solvency under the acceptable level of risk (Baitova, 2014).

To provide financial sustainability to an education institution in currently changing market conditions, it is necessary to constantly monitor the market situation of education services, at the same time critically evaluating its own position in the market. Moreover, the expansion of non-state education institutions' activity has resulted in a dramatically intensified competition in higher education, in an increasing struggle for the survival of state education institutions, in a struggle for every student and every penny.

The systematization of scientific works about financial sustainability evidences the presence of a large number of various methods. The main methods are as follows:

- Comparative analysis and grouping;

- Break-even analysis;

- Coefficient method;

- Integral method;

- Factor analysis and economic and mathematical modeling;

- Matrix method;

- Fuzzy-set-theory-based methods;

- Expert polls.

It is possible to define the financial sustainability of an education institution with the method proposed by Kelchevskaya N. R. (2014). The algorithm is as follows:

1) calculate the absolute indices of the financial sustainability of an education institution (Table 1).

Table 1. Absolute indices of financial sustainability of education institutions (Note 1)

\begin{tabular}{|c|c|c|}
\hline Index & Symbol & Meaning \\
\hline 1. Availability of working capital including: & $\mathrm{E}_{\mathrm{c}}$ & Equity - Fixed assets and invested funds \\
\hline Budgetary funds & $\mathrm{E}_{\mathrm{c} \tilde{\sigma}}$ & Budgetary funds - Fixed assets and invested funds \\
\hline $\begin{array}{l}\text { 2. Availability of working capital and sources of } \\
\text { long-term borrowed funds to form inventory and } \\
\text { expenditures }\end{array}$ & $\mathrm{E}_{\mathrm{T}}$ & Working capital + Long-term debts \\
\hline $\begin{array}{l}\text { 3. Total value of major sources of funds to form } \\
\text { inventory and expenditures }\end{array}$ & $\mathrm{E}_{\mathrm{e}}$ & Working capital + Long-term and short-term debts \\
\hline 4. Surplus or deficiency of working capital & $+/-\mathrm{E}_{\mathrm{c}}$ & Working capital - Inventory and expenditures \\
\hline $\begin{array}{l}\text { 5. Surplus or deficiency of working capital and } \\
\text { sources of long-term borrowed funds to form } \\
\text { inventory and expenditures }\end{array}$ & $+/-\mathrm{E}^{\mathrm{T}}$ & $\begin{array}{l}\text { Working capital and long-term borrowed funds - } \\
\text { Inventory and expenditures }\end{array}$ \\
\hline $\begin{array}{l}\text { 6. Surplus or deficiency of major sources of funds to } \\
\text { form inventory and expenditures }\end{array}$ & $+/-\mathrm{E}_{\mathrm{e}}$ & $\begin{array}{l}\text { (Working capital }+ \text { Long-term and short-term borrowed } \\
\text { funds) - Inventory and expenditures }\end{array}$ \\
\hline
\end{tabular}

2) calculate the 3-D index that allows identifying a proper type of financial sustainability for an education institution:

$$
S=\left\{S_{1}\left(x_{1}\right) ; S_{2}\left(x_{2}\right) ; S_{3}\left(x_{3}\right)\right\}
$$

The function $\mathrm{S}(\mathrm{x})$ is defined as follows: 


$$
S(x)= \begin{cases}0, & x<0 \\ 1, & x \geq 0\end{cases}
$$

3) Define one of four types of financial sustainability (FS):

- Absolute FS - $\mathrm{S}=(1,1,1)$ - features a high level of an education institution's solvency. The sources to cover expenses are working capital.

- Normal FS - $\mathrm{S}=(0,1,1)$ - features a medium level of an education institution's solvency, the efficient use of borrowed funds, and a high profitability. The sources to cover expenses are working capital and long-term debts.

- Unstable FS - S $=(0,0,1)$ - features a low level of an education institution's solvency, the necessity to attract extra funds and the possibility to improve the situation. The sources to cover expenses are working capital, long-term and current debts.

- Critical financial condition - $\mathrm{S}=(0,0,0)$ - features zero solvency of an education institution, on the verge of bankruptcy.

Defining a type of the financial sustainability of an education institution will allow the efficiency of both education and funds allocation to be determined and timely measures to be taken to face the threat of crisis trends in its activity.

One of the most popular methods is also the break-even analysis. This method is applied to determine a minimum range of charged services, required for covering the expenses which are growing due to the performance of such activity.

It is essential to consider that the state covers one part of an education institution's expenses in case this institution is carrying out the state professional training task, guaranteeing a minimum level of its financial sustainability.

The other part of the expenses of an education institution should be covered by extra-budgetary funds. To optimize the estimate of their necessary amount, the break-even point is to be found. This point shows a minimum volume of extra-budgetary funds required for justifying all the expenses of an education institution which haven't been covered by budgetary funds.

The main criteria that determine the financial sustainability of an education institution and the efficiency of its financial activity are liquidity and solvency.

Solvency is defined as an index which shows the possibility of an education institution to pay off its debts from the total assets. To determine institution solvency, the following coefficients should be estimated: the coefficient of general solvency, the debt-to-equity ratio, the equity ratio, the current-assets-to-equity ratio.

Being the integral indicator of solvency, liquidity is an index which characterizes the possibility of an education institution to cover its current liabilities. The analysis of the financial activity of an education institution uses the following indices of liquidity:

- Absolute liquidity ratio;

- Acid-test ratio;

- Current liquidity ratio.

To reverse financially sustainable institution, innovative college and university presidents are doing four things:

1. Developing a clear strategy, focused on the core;

2. Reducing support and administrative costs;

3. Freeing up capital in non-core assets;

4. Strategically investing in innovative models (Denneen \& Dretler, 2014).

It is necessary to point out that, for a more precise result of the financial sustainability analysis, the obtained results should be compared with similar ones in respect of the sphere of education.

There exist the following objectives of estimating financial sustainability:

- To determine social and market needs and to compare them with a definite higher education institution and its competitors;

- To reveal components imposing either a positive or negative influence on the estimated entity; 
- To determine financial and labour reserves for improving economic sustainability;

- To work out a plan to increase financial sustainability.

Financial sustainability can be analyzed periodically for monitoring market needs and existing possibilities to launch new professional training programs and for rising and/or maintaining a higher education institution's competitive power. It can also be a one-time analysis in case of large projects. Federal state budgetary and private higher education institutions provide a list of their FS indices in financial sustainability and financial management efficiency monitoring reports.

There are the following principles of monitoring the quality of financial management and the efficiency of budget expenses:

- To analyze the efficiency of budget expenses;

- To estimate the indices of the entire network of education institutions;

- To define standard values for each index;

- To evaluate the efficiency of a manager's activity by analyzing the quality of financial management.

A general situation associated with monitoring both financial stability and financial management quality in federal state budgetary and private higher education institutions is as follows: 212 higher education institutions, supervised by the Ministry of Education and Science of the Russian Federation, have provided the data and 71 higher education institutions, supervised by the Ministry of Education and Science of the Russian Federation, have provided no data (The Ministry of Education and Science of the Russian Federation).

Here are the complex indices of monitoring both the financial sustainability and financial management quality of higher education institutions, as follows:

1. Indices of budget expenditure efficiency:

1.1. Index of structural earnings;

1.2. Index of quality of income planning;

1.3. Index of quality of estimating expenses from subsidies by certain types of costs;

1.4. Index of quality of estimating expenses from equity by certain types of costs;

1.5. Structural index of immovable property;

1.6. Structural index of most valuable movable property.

2. Indices of financial sustainability (Table 2):

2.1. Share of earnings from income-bearing activities, except earnings from services/works, defined as principal activities on a fee-paid basis in accordance with the Articles;

2.2. Total debt to equity ratio;

2.3. Coefficient of fixed assets renewal;

2.4. Coefficient of non-financial assets increase;

2.5. Share of intangible assets;

2.6. Coefficient of overdue payable accounts;

2.7. Coefficient of non-recoverable receivables.

Table 2. Financial sustainability indices (the Ministry of Education and Science of the Russian Federation)

\begin{tabular}{|c|c|c|c|c|}
\hline Indices & \multicolumn{4}{|c|}{ Threshold values } \\
\hline $\begin{array}{l}\text { 2.1. Share of earnings from income-bearing activities, except earnings from services/works } \\
\text { defined as principal activities on a fee-paid basis in accordance with the Articles }\end{array}$ & \multicolumn{2}{|c|}{$\leq 10 \%$} & \multicolumn{2}{|c|}{$>10 \%$} \\
\hline Number of institutions & \multicolumn{2}{|c|}{130} & \multicolumn{2}{|c|}{82} \\
\hline \multirow{2}{*}{ 2.2. Total debt to equity ratio } & \multicolumn{2}{|c|}{ Budgetary } & \multicolumn{2}{|c|}{ Private } \\
\hline & $<0.3$ & $\geq 0.3$ & $<0.45$ & $\geq 0.45$ \\
\hline Number of institutions & 46 & 146 & 13 & 7 \\
\hline
\end{tabular}




\begin{tabular}{lcc}
\hline Indices & Threshold values \\
\hline 2.3. Coefficient of fixed assets renewal & $<1$ & $\geq 1$ \\
Number of institutions & 201 & 1 \\
2.7. Coefficient of non-recoverable receivables & $\leq 0.03$ & $>0.03$ \\
Number of institutions & 182 & 20 \\
\hline
\end{tabular}

3. Indexes of financial management quality:

3.1. Share of non-core staff payroll in total payroll;

3.2. Share of academic staff bonus payroll;

3.3. Coefficient of average academic staff wages in the accounting period.

A background for establishing the system to monitor financial management quality:

-Prospect for the development of education institutions in economic and financial spheres, which is mainly preconditioned by the human factor, i.e., financial policy conducted by the management staff of an institution;

-Liabilities resulted from the cooperation of education institutions with other contracting parties;

-Lack of detailed methods to monitor the financial management of the activity of budgetary and private education institutions (the Ministry of Education and Science of the Russian Federation).

\section{Conclusion}

Nowadays, the efficient higher education institution must be oriented to solving the following tasks:

- To increase the financial sustainability, economic independence, and flexibility of the management structure of a higher education institution;

- To increase the efficiency of cooperation between higher education institutions and private businesses;

- To increase the efficiency of cooperation between the market for education services and national and regional labor markets, resulting in a more efficient national economy.

Monitoring both the financial sustainability and financial management quality of federal state budgetary and private education institutions should be oriented to revealing their management problems, comparing the existing indices with thresholds and defining the reasons for deviations, changing threshold values in accordance with the analysis of trends for change in evaluation parameters, and developing the recommendations for the management of higher education institutions to attain these parameters.

\section{References}

Baitov, A., \& Grin, A. (2014). Analysis of Financial Sustainability of Public Higher Educational Establishments. Retrieved December 25, 2014, from http://safbd.ru/magazine/article/analiz-finansovoy-ustoychivostigosudarstvennogo-vuza

Belyakov, S. (2012). Education Funding in Russia (p. 304). M.: MAKS-Press.

Benderskaya, O., \& Chizhova, E. (2012). Sustainable Organization and Mechanism of its Sustainability SPb (p. 244). Khimizdat.

Denneen, J., \& Dretler, T. (2014). The Financially Sustainable University. Retrieved December 20, 2014, from http://www.bain.com/Images/BAIN_BRIEF_The_financially_sustainable_university.pdf

Estermann, T., \& Claeys-Kulik, A.-L. (2014). Financially Sustainable Universities. Full Costing: Progress and Practice. Retrieved December 25, 2014, from http://biblioteca.ucv.cl/site/colecciones/manuales_u/Full\%20 Costing\%20Progress\%20and\%20Practice_web\%20(1).pdf

Estermann, T., \& Pruvot, E. B. (2014). Financially Sustainable Universities. European universities diversifying income streams. Retrieved December 25, 2014, from http://www.eua.be/Pubs/Financially_Sustainable_ Universities_II.pdf

Higher Education Funding Council for England. (2014). Department for Business, Innovation and Skills. Retrieved December 20, 2014, from https://www.gov.uk/government/uploads/system/uploads/attachment data/file/293635/bis-14-p188-innovation-report-2014-revised.pdf 
Kelchevskaya, N. (2014). Evaluation of Economic Sustainability of Public Higher Education Institution. Retrieved December 20, 2014, from http://ecsocman.hse.ru/text/16898864

Kharlamova, E. E., \& Sazonov, S. P. (2014). Increase in Efficiency of Activity of Educational Organization in System of Higher Professional Education under Current Management Technologies. World Applied Sciences Journal, 30(10), 1271-1275

Lapovsky, L. (2014). The Higher Education Business Model Innovation and Financial Sustainability, 2014. Retrieved December 25, 2014, from http://agb.org/sites/default/files/legacy/2014_nct_tiaa_cref.pdf

Letter by the Ministry of Education and Science of the Russian Federation No.06-948, 2013. Retrieved December 30, 2014, from http://www.consultant.ru

Rymanov, A. (2010). Financial and Economic Sustainability of Institution: its Essence and Types. Economic Analysis: Theory and Practice, 1, 16-19.

Stanislavchik, E. (2010). Financial Sustainability and Financial Leverage (p. 28). Financial Press.

Sterling, S., Maxey, L., \& Luna., H. (2013). The Sustainable University - progress and prospects, Abingdon: Routledge/Earthscan. Retrieved December 25, 2014, from http://www.routledge.com/books/details/978041 5627740/\#description

Terentyeva, T. V., \& Kulakova, M. N. (2012). Mechanism for Identifying Efficiency and Quality of University Educational Services. Current Problems of Science and Education (p. 6).

The Ministry of Education and Science of the Russian Federation. (2014). Retrieved December 25, 2014, from http://xn--80abucjiibhv9a.xn--p1ai/

\section{Note}

Note 1 . Table 1 is built by the authors, using the data of the research work by Kelchevskaya N. R., 2014 .

\section{Copyrights}

Copyright for this article is retained by the author(s), with first publication rights granted to the journal.

This is an open-access article distributed under the terms and conditions of the Creative Commons Attribution license (http://creativecommons.org/licenses/by/3.0/). 